\title{
The role of financial behaviour, financial literacy, and financial stress in explaining the financial well-being of B40 group in Malaysia
}

\author{
Mahfuzur Rahman ${ }^{1 *}\left(\mathbb{D}\right.$, Che Ruhana Isa ${ }^{1}$, Muhammad Mehedi Masud ${ }^{2}$, Moniruzzaman Sarker $^{3,4^{*}}$ and \\ Nazreen T. Chowdhury ${ }^{1}$
}

\begin{abstract}
Understanding the financial well-being of lower-income group is a critical concern of any government as this group struggles most to meet up with their necessities. Despite the significance, little is known about financial well-being of low-income group. This study attempts to investigate the relationship between financial literacy, financial behaviour, financial stress, and financial well-being of B40 group in Malaysia. A total of 412 usable responses was derived from a survey in Klang Valley and analysed the data following partial least squares structural equation modelling (PLS-SEM) techniques. The results demonstrate that financial behaviour is the key antecedent followed by financial stress and financial literacy in predicting financial well-being. Hence, balancing between income and expenditure, managing financial stress, and increasing financial literacy would be necessary to assure financial well-being of lower-income group people. Governmental and institutional interventions are essential to equip the low-income group people with employment opportunities and financial knowledge to manage their basic living standards.
\end{abstract}

Keywords: Financial well-being, Financial behaviour, Financial literacy, Financial stress, Malaysian B40 income group

\section{Introduction}

Financial well-being is an essential concern for individuals, societies as well as for countries. Generally, well-being encompasses the broad aspect of overall living quality which includes the level of income, job security, housing facilities, quality of living standard, healthcare access, education facilities, environment and social bonding, etc. [39]. Financial well-being is one of the critical aspects of overall well-being [10]. Malaysia is doing good concerning the UN Sustainable

\footnotetext{
*Correspondence: mahfuzur@um.edu.my; mrajib.sarker@gmail.com ${ }^{1}$ Faculty of Business and Accountancy, University Malaya, 50603 Kuala Lumpur, Malaysia

${ }^{3}$ Department of Marketing, Sunway University Business School, Sunway University, Subang Jaya, 47500 Bandar Sunway, Malaysia

Full list of author information is available at the end of the article
}

Development Goals (SDGs), as there is remarkably a low level of unemployment rate, infrastructural development, and high in healthcare satisfaction. As a developing country, the vision of Malaysia is to evolve progressively into a high-income nation by the year 2024. Despite the fluctuation of the universal economy over the past decade, a rising trend in the gross domestic product (GDP) of Malaysia signposts that a positive growth continued throughout the years of 2019. For instance, the Department of Statistics Malaysia (2020) reports a $4.3 \%$ growth of GDP in 2019, which continued to increase in the first quarter of 2020 . These numbers show that the nation could be on track to obtain its sight of becoming a large earning state. It is worth mentioning that the current global pandemic appears as a challenge for every nation and slows down the pace of economic development globally. Hence, along 
with tackling the economic challenge caused by this pandemic, assuring financial well-being is essential for every government to expedite the economic development.

The economic strength of a country is linked to earnings and wealth allocation of the citizen, particularly the poverty level, real per capita income, the Gini co-efficient, construction, in notably transport and communication. The Malaysian Well-being Index (MWI) is used to measure the degree of society's well-being and overall quality of life. The index covers two holistic components of economic and social well-being. The economic well-being components include income and distribution, education, transport, communications, and working life, whereas the social well-being component covers areas such as housing, public safety, culture, health, family, leisure and other social aspects. There are some initiatives taken by the Malaysian government to help low-income households to tackle the stress of increasing cost of living. These measures include the cost of living support (direct cash transfers) to the "B40" (people belonging to the bottom $40 \%$ income group) and gradual increases over the next five years of the monthly minimum wage to MYR 1,500 from the current MYR 1100 [63]. Is signposts that financial well-being is one of the critical drivers of economic development.

The studies on financial well-being have been acknowledged as crucial related to overall well-being. Brüggen et al. [9] define financial well-being as "the perception of being able to sustain current and anticipated desired living standard and financial freedom" (p. 229). A precise understanding of financial well-being may help to initiate an effective economic policy for achieving sustainable living standards. Hence it is necessary to conduct more research to improve a unified set of knowledge on this area. According to Agyei et al. [2], financial well-being refers to "a condition where an individual is satisfied and comfortable with his or her financial situation including the ability to (i) meet current expenses from current income, (ii) save; (iii) maintain debt at sustainable levels; (iv) deal with financial problems; and (v) being generally satisfied with one's financial condition." (p. 224). Financial well-being is not related to micro-level factor only such as individual or organisation; instead, it is a macro-level issue (i.e. national and universal). As mentioned by Hsiao et al. [40], individual financial well-being is a requisite of state balance in society. An individual with unsatisfactory financial well-being not only becomes a burden to themselves or their immediate circles but also has an impact on the health of economic and financial systems of a country [88]. It is since people with financial difficulties may have a negative impact on their productivity, physical health, economic and psychological state [50].

Despite the prior attempts devoted to understanding financial well-being, it is still a fertile area to investigate more due to the lack of proper framework and study setting [49]. For instance, previous literature deems that financial well-being could be dissimilar based upon what is valued most. The value, which remains inside individual, may be affected by financial literacy, financial management, and stress towards finance [16, 73]. Likewise, the relationship between financial literacy, types of money attitudes, debt management have a positive influence on financial well-being [1]. On the other hand, Xue et al. [94] described that financial literacy significantly improves financial well-being and has a positive effect on financial well-being. Delafrooz and Paim [16] investigated the relationships between financial literacy, financial management practices and financial stress influenced financial problems and saving behaviour. Mokhtar and Husniyah [58] reported that financial stress, work environment, locus of control and financial behaviour were significantly associated with the financial well-being of Malaysian public sector employees. Mahdzan et al. [56] investigated subjective well-being of different income groups in Malaysia and reported a significant difference exists among the groups concerning financial behaviour, internal locus of control, financial knowledge, and financial stress. Despite these efforts, predicting key antecedent of financial well-being among the lowerincome group people is still scary. To address this gap, we accounted for the variables such as financial behaviour, financial literacy, and financial stress which are directly and indirectly manifested by behavioural factors external to the individual. Even though these three predictors have been discussed in the literature, they received few attentions in the lower-income group setting. Hence, this study considers financial behaviour, financial literacy, and financial stress in predicting financial well-being of B40 income group in Malaysia. Precisely, this study aims at(1) investigating the key factors affecting financial wellbeing and (2) exploring which demographic variables account for the significant difference within the study variables among the low-income group in Malaysia.

\section{Literature review and research framework Financial well-being}

Most commonly, financial well-being implies the financial circumstance as well as enough money to meet 
one's needs with security and freedom of choice. Various educational disciplines have been studied in financial well-being including economics, financial advising and organisations, developmental psychology, consumer decision-making and services marketing. Several scholars define financial well-being with different perspectives. For instance, according to Brüggen et al. [9], financial well-being is the perception of being able to preserve present and expected aspiration for living standards and financial freedom. Financial well-being refers to an objective and subjective concept, where it contributes to an individual's evolution of his/her current financial condition [87]. Similarly, financial well-being can meet for needs and liability of recent and anticipated lifestyle [9, 51]. Muir et al. [59] ascertained that the strongest influencers of financial well-being are financial capability, financial inclusion, social capital, income, and (mental) health. The influence of financial well-being extends far ahead of the financial context. For example, Netemeyer et al. [60, p. 68] found in the USA that perceived financial well-being is "a key predictor of overall well-being and comparable in magnitude to the combined effect of other life domains". Positive perception of financial well-being endures happiness, feeling, encouragement, excellent health, and well-established mutual relationships $[48,86]$. On the other hand, negative perception of financial wellbeing may cause worry, brutality, exhaustion as we as weak health $[8,23]$. Similarly, Evidence shows that poor financial well-being can affect physical, mental and social well-being, which in turn can result in poor job performance, short-term decision-making, a reduced ability to concentrate, absenteeism and lower productivity [64].

\section{Financial behaviour}

Financial behaviour can perform a central role where individuals' well-being including household, society, nation as well as around the world can be influenced by financial behaviour. According to Perry and Morris [66], financial behaviour is defined as the management of a person's savings, expenditure, and budget, whereas Xiao [92] asserts that human activities related to money management such as cash, savings, and credit are regarded as financial behaviour. In a wider view, financial behaviour includes broad concepts including investment behaviour for short-term and long-term, savings behaviour, credit usage, expenditure behaviour, etc. [26]. This study conceptualises financial behaviour based on Xiao [92]'s definition as regular money management of cash, savings, and credit is more relevant to people in the bottom line.
Brüggen et al. [9] report that financial behaviour has a direct effect on financial well-being. Similarly, Joo and Grable [47] postulate that financial well-being is, directly and indirectly, related to financial behaviour. According to Falahati et al. [21], financial behaviour refers to the individual ability to operate their finances to become successful in their life. In another study by Klontz and Britt [55], individual financial behaviour means to the financial management capabilities acquired by them. There have also been several previous studies that explained financial behaviour from different perspectives. For instance, individual's aspect of financial concepts such as financial behaviour associates with financial management techniques $[55,89]$ and their financial satisfaction $[5,21]$. Financial behaviour and financial knowledge related to individuals' financial satisfaction $[68,75]$. On the other hand, Osman et al. [64] researched the federal territory of Labuan in Malaysia and reported that there was no significant relationship between financial behaviour and financial well-being. In the same manner, Taft et al. [85] investigated the correlation between financial literacy, financial well-being and financial concerns. Their findings showed that age and education were positively connected to financial literacy and financial well-being. Thus, it is assumed that financial behaviour might have positively influenced on financial well-being of lowerincome group in Malaysia. Based on this discussion, this study is hypothesised that:

H1. Financial behaviour has a positive effect on financial well-being.

\section{Financial literacy}

Financial literacy implies the capacity to understand and examine options for funding, preparing for the future, and responding adequately to the situations. Financial literacy also provides individual's successful experience to involve in economic activities via increased deposits, appropriate buying decision, correct investing, land management, employing security, debt as well as enhancing the financial well-being. According to Kaur et al. [50], financial literacy is a necessary life ability for individuals to gain financial well-being. Similarly, Remund [71] postulates that financial literacy means a person's ability to understand and use financial matters. Hung et al. [42] define financial literacy as "knowledge of basic economic and financial concepts, as well as the ability to use that knowledge and other financial skills to manage financial resources effectively for a lifetime of financial well-being" (p. 12). Huston [44] explains that "financial literacy 
should be conceptualized as having two dimensionsunderstanding (personal finance knowledge) and use (personal finance application)" (p. 306). Xiao et al. [93] measured financial literacy using an individual's understanding of financial knowledge (subjective knowledge) and accurate, stored knowledge regarding credit content (objective knowledge). As marginalised community might have limited access to the personal finance application due to low-income level, this study focuses mainly on the understanding of personal financial knowledge to define financial literacy.

Financial literacy plays a significant role to make financial decisions in retiring households [94]. Previous research affirmed a positive relationship between financial literacy and financial well-being [11, 30, 82]. It asserts that retired households with high-level financial literacy are more probably to be pleased with their financial situation. Dvorak and Hanley [20] studied financial literacy and designing retirement plans. Their findings show that a lower level of financial literacy among people was found among low income and low education group and respondents in consulting and finance training courses lead to raising financial literacy. The study of Xiao et al. [93] on consumer financial capability and financial satisfaction postulated that financial ability, laudable financial behaviour and subjective financial literacy positively contribute to financial well-being. Therefore, based on this discussion, this study proposed that:

H2. Financial literacy has a positive effect on financial well-being.

\section{Financial stress}

Financial stress could be defined as complexity engagement, general financial responsibilities due to lack of money. It is also one's unpleasing feeling that an individual is incapable of fulfilling financial needs, managing the living requirements and having adequate finances to make ends meet. Davis and Mantler [15] assert that stress involves the impressions of frightening, distress and scare, but may also anger and dissatisfaction. It is a point to note that the concept of financial stress and financial distress are not similar [56]. Financial stress is related to the major financial inadequacies to meet up individual financial needs, whereas financial distress is an opposite viewpoint of financial well-being. Financial stress primarily derives from the inadequacy of fund due to personal, family, and shocks in financial situations $[47,69]$. The increase of financial stress, such as debt increase or financial shortages, would reasonably intensify the state of financial distress [7], which lowers the level of financial well-being. One of the key concerns of marginalised community is having a lack of enough finance which put them into financial constrain and economic hardship.

Steen and MacKenzie [84] explain that financial stress raises the endanger of hopelessness and negatively affects an individual's health and psychological well-being. Similarly, financial stress may also drive negative results, such as lower job performance $[46,53,62]$ as well as diminishes overall well-being including state of health [19, 52]. Bialik [6] reported that $45 \%$ of employees, who had financial challenges, were more stressful in their lives, jobs, health or relationships combined. The study of Netemeyer et al. [60] explains that financial literacy has a small negative partial impact on perceived future financial security and there was no effect on money management stress. It is also recognised that buyers are more vulnerable with their lower income and loss of financial well-being due to their lower levels of financial reserves [31]. Grable and Joo [29] reported that college students' credit card debt increases their financial stress. Thus, based on these arguments, this study is postulated that:

$H 3$. Financial stress has a negative effect on financial well-being.

Financial literacy has a direct effect on financial wellbeing [30, 82]. Similarly, Xiao et al. [93] found that subjective financial literacy positively contributes to financial well-being. Financial behaviour is also found to have positive effect on financial well-being [9]. It is also found that individual's aspect of financial concepts, such as financial behaviour associates with financial management techniques [89] and their financial satisfaction [5]. However, Kaur et al. [50] argued that financial literacy is a necessary life ability for individuals to gain financial well-being. In contrast, financial stress is found to have negative effect on job performance [53,62] and overall well-being. It is also documented in the literature that the increase of financial stress, such as debt increase or financial shortages, would reasonably intensify the state of financial distress [7], which lowers the level of financial well-being. Based on the above discussion, it is assumed that financial behaviour might mediate the relationship between financial literacy and financial well-being as well as financial stress and financial well-being. Therefore, this study is hypothesised that:

H4. Financial stress has a negative effect on financial behaviour.

H5. Financial literacy has a positive effect on financial behaviour.

H6. Financial behaviour mediates the relationship between financial stress and financial well-being. 


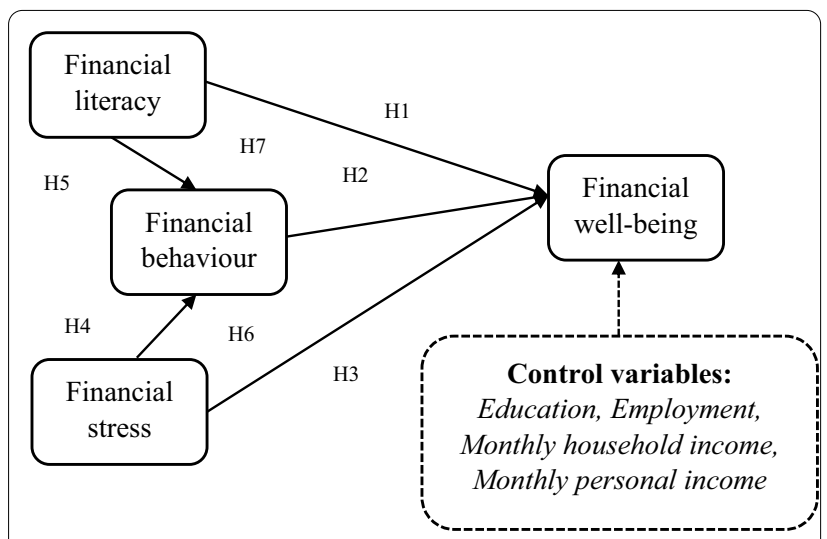

Fig. 1 Research framework

H7. Financial behaviour mediates the relationship between financial literacy and financial well-being.

The above discussion leads to conceptualising a framework that explains the financial well-being of B40 income group in Malaysia. Previous studies such as Mahdzan et al. [56] examined the financial well-being of Malaysians based on the differences in demographic factors. Hence, to explore the sustained effect of study variables on FWB, we have included four demographic factors in the research model (Fig. 1).

\section{Methods}

\section{Variable measurement and questionnaire design}

This study adapted previously validated scales to measure the study variables. An eight-item scale of Prawitz et al. [69] was adapted for measuring financial well-being (FWB) and measured by 5 -point Likert-scale ranging from $1=$ very unhappy to $5=$ very happy. Likewise, financial behaviour (FB) was measured using a ten-item scale adapted from Garman et al. [27] and financial stress (FS) was measured by six items adapted from Grable et al. [28]. Responses of these two scales were anchored using a 5 -point Likert scale ranging from $1=$ strongly disagree to $5=$ strongly agree, whereas a total of ten-items scale by Sabri et al. [74] was adapted to measure financial literacy (FL). Respondents were provided with the option "True" and "False" for each item. 'True' was rated as ' 1 ' and otherwise ' 0 ' was assigned from the option 'False'. Out of these ten items, an overall score for measuring FL was obtained based on the total number of 'True' chosen by the respondents.

After the initial selection of measurement scales, a structured questionnaire was designed. This questionnaire was then pre-tested with three academic experts and five participants to confirm the meaning, wording, flow, and comprehensibility of the items [43]. There were few minor concerns which were taken into consideration for revising the question statement (see Appendix A). Besides, the questionnaire was translated into Bahasa Malaysia and checked by a professional editor. The interpreted version of questionnaire (i.e. Bahasa Malaysia version) was again translated back to English to confirm the meaning and content validity of the scale [56]. Finally, both English and Bahasa Malaysia languages were used to design the questionnaire.

\section{Sampling and data collection}

The target respondents of this study were Malaysian citizens whose income is around RM 5, 000 or less in a month. According to the Department of Statistics Malaysia [18], the highest population in Malaysia lives in Klang Valley. As a majority of the Malaysian population lives in this region, surveying Klang Valley is suitable for this research. Considering the nature of sample composition, application of the probability sampling method would not be realistic. Scholars explain that careful execution of a survey using non-probability sampling can yield a representative group of a sample if the respondents are chosen based on specific criteria fixed before the survey [77]. Hence, questionnaires were distributed among the target respondents following purposive sampling technique setting up two criteria, such as education and lowincome groups. During the survey period, a total of 467 questionnaires were received. Due to the missing values in the questionnaire, 55 responses were discarded which resulted in a total number of 412 questionnaires as usable responses.

\section{Estimation method}

The conceptual model of this study was analysed using Partial least squared structural equation modelling (PLSSEM) rather than co-variance-based squared structural equation modelling (CB-SEM) techniques. PLS-SEM entails comparative advantages over CB-SEM such as suitability in explorative research, target prediction, flexibility in handling non-normal data and small sample sizes $[35,80]$. As this research aims at predicting and explaining the key variable such as financial well-being, the PLS-SEM technique is highly suitable. Moreover, concerning any sample size and, or any distributed data, the PLS-SEM method attains superior statistical power [32-34]. This study used SmartPLS 3.3.2 [72] to analyse 
the model, whereas SPSS v23 was utilised to conduct descriptive analysis and F-test, respectively.

We analysed the research model following two-steps procedures recommended in Hair et al. [36, 37]. At the first step, measurement scales are examined based on composite reliability, convergent validity and discriminant validity. Once the measurement model is satisfied with benchmark values, in the second step, the structural model is assessed for hypotheses testing, prediction accuracy. Hair et al. [36, 37] emphasise that traditional metrics of assessing model prediction such as $\boldsymbol{R}^{2}, \boldsymbol{f}^{2}$ and cross-validated redundancy $Q^{2}$ provide findings concerning prediction accuracy within the sample group (in-sample prediction) only, whereas the out-of-sample predictive accuracy assessment explains the predictive ability of a research model beyond the sample group of respondents [83]. In the SEM, in-sample prediction is not enough to come to a conclusion about prediction accuracy of a theoretical model. Hence, we employed the PLS predict technique in Shmueli et al. [83] to evaluate the out-of-sample prediction accuracy of the study model.

\section{Results}

\section{Descriptive analysis of the participants}

Descriptive statistics results show that the sample consisted of mostly the age group of 25 to 34 (about 59\%), female (about 90\%), Bumiputera Melayu (91\%), and Muslim (about 93\%). Besides, about $68 \%$ of the respondents' monthly was below RM 3,000 which confirms the nature of target respondents of the study. The details of the respondents' profile are presented in Table 1.

Study variables (such as FWB, FS, FB and FL) were also investigated regarding group differences within the demographic components. Using ANOVA analysis results in Table 2 exhibit that the magnitude of financial well-being and financial literacy significantly varied based on the education level of respondents. Type of employment was one of the essential factors for which level of financial well-being, financial behaviour and financial literacy significantly was significantly diverse. Precisely, self-employed and government job holder exerts a higher level of FWB, FB and FL. Moreover, the amount of monthly household income was a significant indicator for a higher level of FWB and FB, while FB was significantly varied based on the level of monthly individual income only. The analysis also exhibits that respondent's financial stress was not significantly varied based on any demographic components. It indicates that there might be some psychological aspects such as risk-taking mentality, lifestyle, confidence in facing challenges, etc., are accounted for the level of financial stress of B40 income group. Overall, among the demographic variables, education, type of employment, income level was the essential aspects in varying the level of FWB, FB, FL among the Malaysian low-income citizen. Hence, we included these demographic variables as control factors to assess the stability effect of FL, FB and FS on FWB.

Table 1 Respondents' profile $(\mathrm{N}=412)$

\begin{tabular}{|c|c|c|c|c|c|c|c|}
\hline Variables & & No & $(\%)$ & Variables & & No & (\%) \\
\hline \multirow[t]{5}{*}{ Age (Years) } & Below 25 & 126 & 30.58 & Residential area & Urban & 354 & 85.92 \\
\hline & $25-34$ & 245 & 59.47 & & Rural & 58 & 14.08 \\
\hline & $35-44$ & 23 & 5.58 & Education & SPM and Certificate & 66 & 16.02 \\
\hline & $45-54$ & 14 & 3.40 & & Diploma & 110 & 26.70 \\
\hline & 55 or Above & 4 & 0.97 & & Bachelor degree & 194 & 47.09 \\
\hline \multirow[t]{2}{*}{ Gender } & Male & 43 & 10.44 & & Master degree & 40 & 9.71 \\
\hline & Female & 369 & 89.56 & & PhD & 2 & 0.49 \\
\hline \multirow[t]{4}{*}{ Ethnicity } & Bumiputera & 376 & 91.26 & Employment & Government sector & 74 & 17.96 \\
\hline & Chinese & 11 & 2.67 & & Private sector & 231 & 56.07 \\
\hline & Indian & 9 & 2.18 & & Self-employed & 57 & 13.83 \\
\hline & Others & 16 & 3.88 & & Non-employed & 50 & 12.14 \\
\hline \multirow[t]{4}{*}{ Religion } & Islam & 385 & 93.45 & Monthly personal income (RM) & 5000 or more & 43 & 10.44 \\
\hline & Christian & 16 & 3.88 & & 4000-4999 & 30 & 7.28 \\
\hline & Buddha & 3 & 0.73 & & 3000-2999 & 58 & 14.08 \\
\hline & Hindu & 8 & 1.94 & & 2000-2999 & 134 & 32.52 \\
\hline \multirow[t]{4}{*}{ Marriage } & Single & 256 & 62.14 & & 1999 or less & 147 & 35.68 \\
\hline & Married & 155 & 37.62 & Monthly household income (RM) & 8000 or more & 58 & 14.08 \\
\hline & Widowed & 1 & 0.24 & & 4000-7999 & 137 & 33.25 \\
\hline & Divorced & 0 & 0.00 & & 3999 or less & 217 & 52.67 \\
\hline
\end{tabular}


Table 2 Group mean differences of demographic components on study variables

\begin{tabular}{|c|c|c|c|c|c|c|c|c|c|}
\hline \multirow[t]{2}{*}{ Variables } & & \multicolumn{2}{|c|}{$\begin{array}{l}\text { Financial } \\
\text { well-being }\end{array}$} & \multicolumn{2}{|c|}{$\begin{array}{l}\text { Financial } \\
\text { stress }\end{array}$} & \multicolumn{2}{|c|}{$\begin{array}{l}\text { Financial } \\
\text { behaviour }\end{array}$} & \multicolumn{2}{|c|}{$\begin{array}{l}\text { Financial } \\
\text { literacy }\end{array}$} \\
\hline & & Mean & $F$ & Mean & $F$ & Mean & $F$ & Mean & $F$ \\
\hline \multirow[t]{5}{*}{ Age (Years) } & Below 25 & 3.49 & 1.74 & 2.97 & 0.39 & 3.41 & 0.95 & 4.12 & 1.81 \\
\hline & $25-34$ & 3.51 & & 2.90 & & 3.43 & & 4.27 & \\
\hline & $35-44$ & 3.61 & & 2.93 & & 3.45 & & 4.57 & \\
\hline & $45-54$ & 3.23 & & 2.83 & & 3.51 & & 4.71 & \\
\hline & 55 or Above & 3.94 & & 2.50 & & 3.78 & & 6.00 & \\
\hline \multirow[t]{3}{*}{ Marital status } & Single & 3.47 & 2.02 & 2.92 & 0.56 & 3.40 & 2.47 & 4.35 & 1.20 \\
\hline & Married & 3.56 & & 2.90 & & 3.49 & & 4.12 & \\
\hline & Widowed & 2.88 & & 3.83 & & 3.10 & & 3.00 & \\
\hline \multirow[t]{5}{*}{ Education } & SPM & 3.52 & $3.64^{* *}$ & 2.93 & 0.97 & 3.39 & 0.75 & 4.03 & $3.71^{* *}$ \\
\hline & Diploma & 3.55 & & 3.00 & & 3.42 & & 4.18 & \\
\hline & Bachelor degree & 3.45 & & 2.92 & & 3.45 & & 4.20 & \\
\hline & Master degree & 3.59 & & 2.69 & & 3.40 & & 5.18 & \\
\hline & $\mathrm{PhD}$ & 4.75 & & 2.59 & & 3.80 & & 5.00 & \\
\hline \multirow[t]{4}{*}{ Employment } & Government sector & 3.51 & $3.19^{*}$ & 2.89 & 0.86 & 3.43 & $4.62^{* *}$ & 4.72 & $2.98^{*}$ \\
\hline & Private sector & 3.46 & & 2.91 & & 3.46 & & 4.08 & \\
\hline & Self-employed & 3.71 & & 2.82 & & 3.48 & & 4.33 & \\
\hline & Non-employed & 3.46 & & 3.09 & & 3.23 & & 4.38 & \\
\hline \multirow[t]{5}{*}{ Monthly personal income (RM) } & 5000 or more & 3.63 & 1.09 & 2.72 & 1.80 & 3.67 & $5.77^{* *}$ & 4.72 & 0.88 \\
\hline & 4000-4999 & 3.44 & & 3.14 & & 3.37 & & 4.33 & \\
\hline & 3000-2999 & 3.43 & & 2.75 & & 3.53 & & 4.23 & \\
\hline & 2000-2999 & 3.53 & & 2.87 & & 3.41 & & 4.21 & \\
\hline & 1999 or less & 3.49 & & 2.98 & & 3.36 & & 4.22 & \\
\hline \multirow[t]{3}{*}{ Monthly household income (RM) } & 8000 or more & 3.68 & $4.13^{*}$ & 2.71 & 1.52 & 3.67 & $21.28^{* *}$ & 4.33 & 0.28 \\
\hline & 4000-7999 & 3.44 & & 2.93 & & 3.49 & & 4.38 & \\
\hline & 3999 or less & 3.50 & & 2.93 & & 3.32 & & 4.24 & \\
\hline
\end{tabular}

Significance at $* p<0.05 ; * * p<0.01$

Table 3 Level of financial well-being (FWB) of the respondents

\begin{tabular}{lllll}
\hline Items & Mean & Min & Max & SD \\
\hline FWB1 & 3.52 & 1 & 5 & 0.76 \\
FWB2 & 3.36 & 1 & 5 & 0.82 \\
FWB3 & 3.47 & 2 & 5 & 0.79 \\
FWB4 & 3.46 & 2 & 5 & 0.75 \\
FWB5 & 3.41 & 1 & 5 & 0.79 \\
FWB6 & 3.70 & 1 & 5 & 0.99 \\
FWB7 & 3.69 & 2 & 5 & 0.77 \\
FWB8 & 3.42 & 1 & 5 & 0.75 \\
\hline
\end{tabular}

Furthermore, the level of FBW was estimated using descriptive statistics. Results in Table 3 demonstrate that there is a moderate level of financial well-being subsists among the study respondents. All the items measuring
FWB scored an average value ranged from 3.70 to 3.36 . However, a mean score of $3.70($ Mean $=3.70 ; \mathrm{SD}=0.99)$ was calculated in the item FWB6 stating-"how frequently do you find yourself eagerly awaiting for the next payday?" which is the highest among 8 items. Likewise, item FWB7 (Mean = 3.69; SD = 0.77), FWB1 (Mean = $3.51 ; \mathrm{SD}=0.76)$, scored an average value of 3.50 or above indicating much effort should be taken to ensure a satisfactory level of FWB of the study respondents.

\section{Assessment of data distributions}

Before analysing the model using PLS-SEM techniques, it is important to check data distributional to explore multivariate assumptions are met $[76,80]$. Using WebPower calculator (https://webpower.psychstat.org/models/kurto sis/), data were investigated for normality of data distribution. The results show that the univariate skewness 
ranged from 0.067 to 0.374 and the kurtosis ranged from -0.677 to -0.017 , indicating data is univariate normal $[13,32-34]$. Regarding multivariate normality assessment, skewness was found to be non-normal (e.g. skewness was significant at $p<0.05)$, whereas multivariate kurtosis was found nonsignificant $(p=0.33)$ indicating normal distribution (see Appendix B). Thus, it can be assumed that data is normally distributed having little concern for multivariate normality. Next, multicollinearity was assessed based on the tolerance and variance inflation factor (VIF) using SPSS v23. Tolerance level of the variables was ranged from 0.833 to 0.947 which are higher than 0.20, and all the VIF values (see Appendix C) were below 5 (e.g. VIF is ranged from 1.056 to 1.201), demonstrating that multicollinearity is not a concern in the findings [13, 32-34, 70]. Besides, a homoscedasticity test was performed to explore the linearity assumption. The result in scatter plots exhibits that standardised residual and predicted values are parallel to each other and plotted close to the regression line (see Appendix D). Thus, the linearity assumption is established [13].

\section{Assessment of common method biases (CMB)}

This study also addresses the issues related to CMB. Following the guidelines in Podsakoff et al. [67], both procedural and statistical remedies were taken into consideration in this research. First, the questionnaire was pretested with three academic experts and five participants to confirm that all the questions were easily comprehensible. Besides, a minor revision was considered in the sentence structure following the suggestion during the pretesting of survey instruments. Second, four reverse coded items were used in the questionnaire. Concerning statistical remedies, it is recommended to apply multiple techniques to assess the presence of CMB in the research findings $[67,81]$. Third, as a statistical procedure, this study performed Harman's single factor test to investigate the common method variance (CMV) using SPSS v23. Harman's single factor test is acknowledged as a reliable test to examine the level of CMV which may cause a bias finding [32-34]. Following the guidelines, result in Appendix E shows that out of a total $58.17 \%$ variance, the first unrotated factor accounted for a variance

Table 4 Latent variable correlations results

\begin{tabular}{llllll}
\hline Constructs & $\mathbf{1}$ & $\mathbf{2}$ & $\mathbf{3}$ & $\mathbf{4}$ \\
\hline 1 & Financial Behaviour & 1 & & & \\
2 & Financial Literacy & 0.044 & Single item & & \\
3 & Financial Stress & -0.266 & -0.23 & 1 & \\
4 & Financial Well-being & 0.485 & 0.236 & -0.405 & 1 \\
\hline
\end{tabular}

of $26.67 \%$ which is below than a threshold level of $50 \%$. This finding supports that CMB is not of any concern in this research $[25,76]$. Besides, another statistical technique named as latent variable correlation matrix procedure by Bagozzi and Yi [4] was followed to investigate the CMV. Using the SmartPLS 3.3.2 result in Table 4 outlines that a correlation score of 0.485 exists between financial behaviour and financial well-being which is the largest among all and below the cut-off level of 0.90 . Therefore, this approach also substantiates that CMB is not a concern in the findings $[57,65]$.

\section{Measurement model analysis}

The theoretical model of this study consists of a total of three latent variables, such as financial behaviour (FB), financial stress (FS), and financial well-being (FWB) and one observed variable named financial literacy (FL). Following the PLS-SEM method, constructs' reliability and convergent validity are evaluated using composite reliability (CR), Dijkstra and Henseler's rho, factor loading, and average variance extracted (AVE) [33]; [36, 37]. Using the SmartPLS 3.3.2, the model was analysed following the standard algorithm criteria [33].

The initial assessment of construct reliability was met for FS and FWB but not for FB. Out of a total of ten items of FB, FB5, FB6, FB8 and FB9 resulted in very poor factor loadings (e.g. the highest factor loading among these four items is 0.29 ) which also caused a very low AVE of 0.277 (see Fig. 2). The deletion of these four indicators may increase the value of AVE. However, Wieland et al. [90] recommend that the researcher has to think of the comprehensiveness of the measurement theory before deleting the indicators based on statistical results. Hence, this study re-visited the measurement properties of FB using exploratory factor analysis (EFA) following the assumption of principal axis factoring (PAF) as indicated in Sarstedt and Mooi [79]. PAF allows for exploring the underlying measurement dimension of a latent construct [79].

EFA test indicated that The Kaiser-Meyer-Olkin (KMO) value was 0.77 and the Bartlett's test of sphericity was significant at $p<0.001$. Following the extraction method as Principal Axis Factoring (PAF), two dimensions were extracted. The items FB1, FB2, FB3, FB4, FB7, and FB10 were loaded into one group, which is regarded as savings behaviour, whereas the items FB5, FB6, FB8, and FB9 were loaded into another group indicating the expenditure behaviour of the respondents. Due to the poor factor loading during EFA, item FB10 and FB5 were discarded, which were lower than 0.40 [22, 35, 41]. Besides, Cronbach's Alpha of these two constructs also met the satisfactory criteria of 


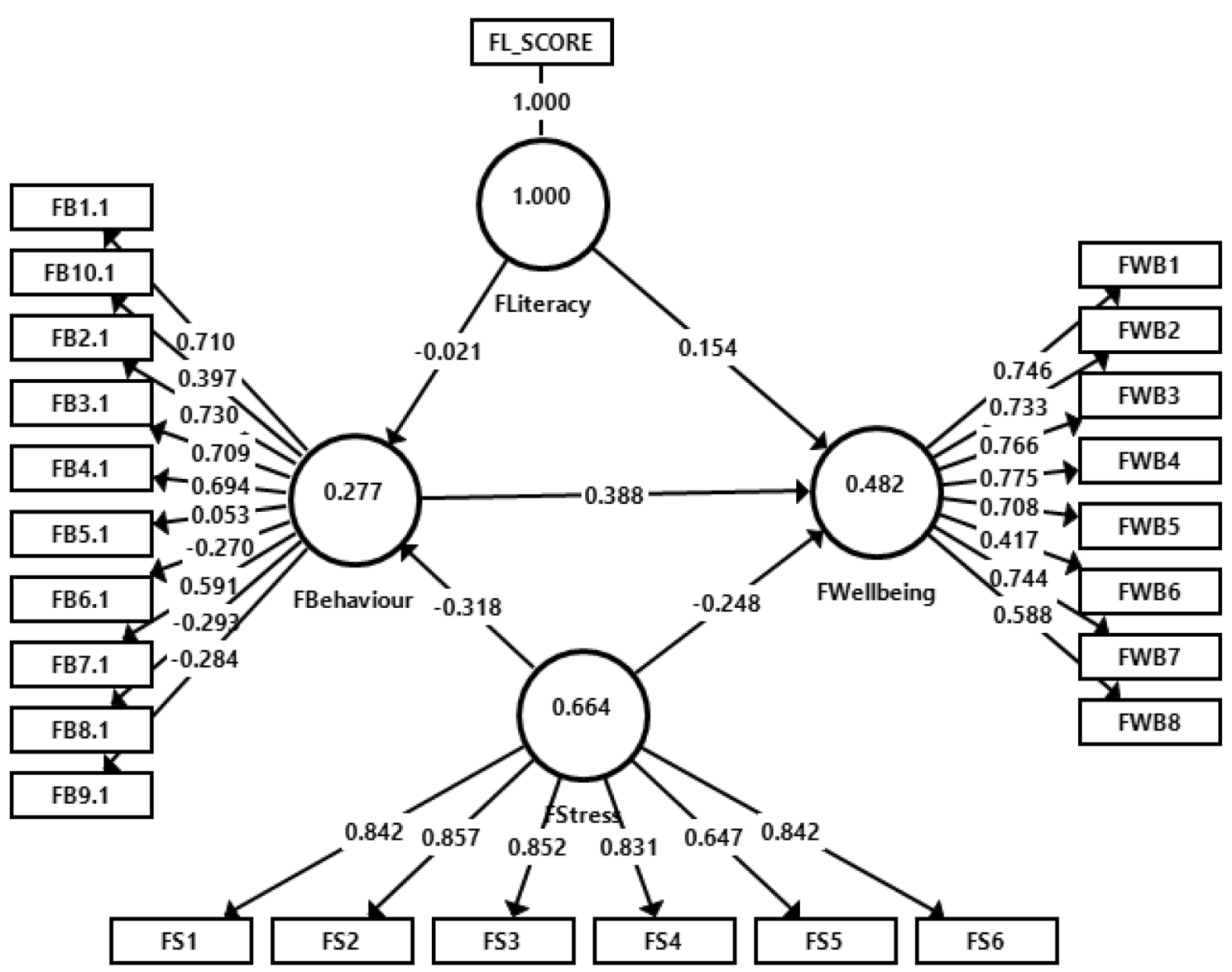

Fig. 2 Initial results of measurement model analysis (Loadings and AVE)

above 0.60 due to the exploratory study [61, 70] [see Appendix E].

Based on the EFA results, FB construct is conceptualised as a second-order reflective measure with two reflectively measured dimensions regarded as type I higher-order construct [78]. The theoretical model is re-evaluated for assessing the properties of measurement scale using SmartPLS 3.3.2 (see Table 5. According to the standard, composite reliability (CR is higher than 0.70 , factor loading should be higher than 0.70, and AVE should be above 0.50 to assure the reliability and convergent validity of the measurement model [33]; [80]. As shown in Table 5, CR is ranged from 0.71 to 0.92 . Likewise, Dijkstra and Henseler's rho is also above 0.70, indicating a satisfactory level of internal consistency reliability. All the factor loadings except for the item FWB8 (loading $=0.59$ ), FB7 (loading $=0.64$ ), and loading of 0.52 resulted in expenditure (the first-order dimension for savings behaviour) which are above the recommended level of 0.70. Although loadings of these three items were below the threshold level, the AVE values of all the latent constructs are above 0.50, indicating an acceptable level of convergent validity. That is why these three items were not deleted despite having low loadings [70, 80].

Discriminant validity was also investigated based on the HTMT criteria. A stringent criterion of $0.85\left(\mathrm{HTMT}_{0.85}\right)$ suggested by Kline [54] was set to assess the discriminant validity due to the conceptual definition of latent variables [24]. According to this criterion, any value of HTMT correlation should be 0.85 or below. Results in Table 6 exhibit that the largest correlation value of 0.509 resulted between FWB and FB. Also, none of the values of $95 \%$ bias-corrected and accelerated confidence interval include 1 between the lower and upper limit of the correlation assuring discriminant validity is achieved [24, 38]. Therefore, reliability and validity of measurement model 
Table 5 Reliability and convergent validity of the measurement model

\begin{tabular}{|c|c|c|c|c|c|c|c|c|}
\hline First-order construct & Second-order construct & Items & Loadings & Mean & SD & rho_A & CR & AVE \\
\hline \multirow[t]{5}{*}{ Savings Behaviour } & & FB1 & 0.73 & 3.85 & 0.81 & 0.76 & 0.84 & 0.51 \\
\hline & & FB2 & 0.74 & 4.02 & 0.74 & & & \\
\hline & & FB3 & 0.74 & 4.01 & 0.71 & & & \\
\hline & & FB4 & 0.71 & 3.82 & 0.76 & & & \\
\hline & & FB7 & 0.64 & 3.69 & 0.70 & & & \\
\hline \multirow[t]{5}{*}{ Expenditure Behaviour } & & FB6 & 0.75 & 2.85 & 1.04 & 0.70 & 0.83 & 0.62 \\
\hline & & FB8 & 0.78 & 3.17 & 0.96 & & & \\
\hline & & FB9 & 0.83 & 2.95 & 0.93 & & & \\
\hline & Financial Behaviour (FB) & Savings & 0.93 & $N / A$ & $N / A$ & $N / A$ & 0.71 & 0.57 \\
\hline & & Expenditure & 0.52 & $N / A$ & $N / A$ & & & \\
\hline \multirow[t]{6}{*}{ Financial Stress (FS) } & & FS1 & 0.84 & 3.04 & 1.02 & 0.91 & 0.92 & 0.67 \\
\hline & & FS2 & 0.86 & 3.07 & 1.02 & & & \\
\hline & & FS3 & 0.86 & 3.06 & 1.04 & & & \\
\hline & & FS4 & 0.83 & 3.00 & 1.11 & & & \\
\hline & & FS5 & 0.64 & 2.52 & 1.23 & & & \\
\hline & & FS6 & 0.84 & 2.79 & 1.12 & & & \\
\hline \multirow[t]{7}{*}{ Financial Well-being (FWB) } & & FWB1 & 0.75 & 3.52 & 0.76 & 0.86 & 0.89 & 0.53 \\
\hline & & FWB2 & 0.75 & 3.36 & 0.82 & & & \\
\hline & & FWB3 & 0.78 & 3.47 & 0.79 & & & \\
\hline & & FWB4 & 0.79 & 3.46 & 0.75 & & & \\
\hline & & FWB5 & 0.71 & 3.41 & 0.79 & & & \\
\hline & & FWB7 & 0.73 & 3.69 & 0.77 & & & \\
\hline & & FWB8 & 0.59 & 3.42 & 0.75 & & & \\
\hline
\end{tabular}

$\mathrm{CA}=$ Cronbach's Alpha; rho_A =Dijkstra and Henseler's rho; $C R=$ Composite reliability; AVE = Average variance extracted; FWB6 was deleted due to low factor loading

Table 6 Discriminant validity of the construct using HTMT

\begin{tabular}{llllll}
\hline Constructs & FB & FL & FS & FWB \\
\hline 1 & FB & & & \\
2 & FL & 0.07 & & \\
& & {$[0.02 ; 0.10]$} & & \\
3 & FS & 0.45 & 0.24 & \\
& & {$[0.35 ; 0.56]$} & {$[0.14 ; 0.34]$} & \\
4 & FWB & 0.51 & 0.26 & 0.46 \\
& & {$[0.41 ; 0.59]$} & {$[0.16 ; 0.35]$} & {$[0.35 ; 0.56]$} \\
\hline
\end{tabular}

Values in the parentheses are the $95 \%$ bias-corrected and accelerated confidence interval

is established. Next, structural model was examined to hypotheses testing.

\section{Hypotheses testing}

After having a satisfactory level of measurement model analysis, a structure model assessment was carried out (see Fig. 3). Hypotheses were examined using the bootstrap techniques (5,000 bootstrap subsamples) as suggested in Ali et al. [3], Sarstedt et al. [80] [see Table 7].

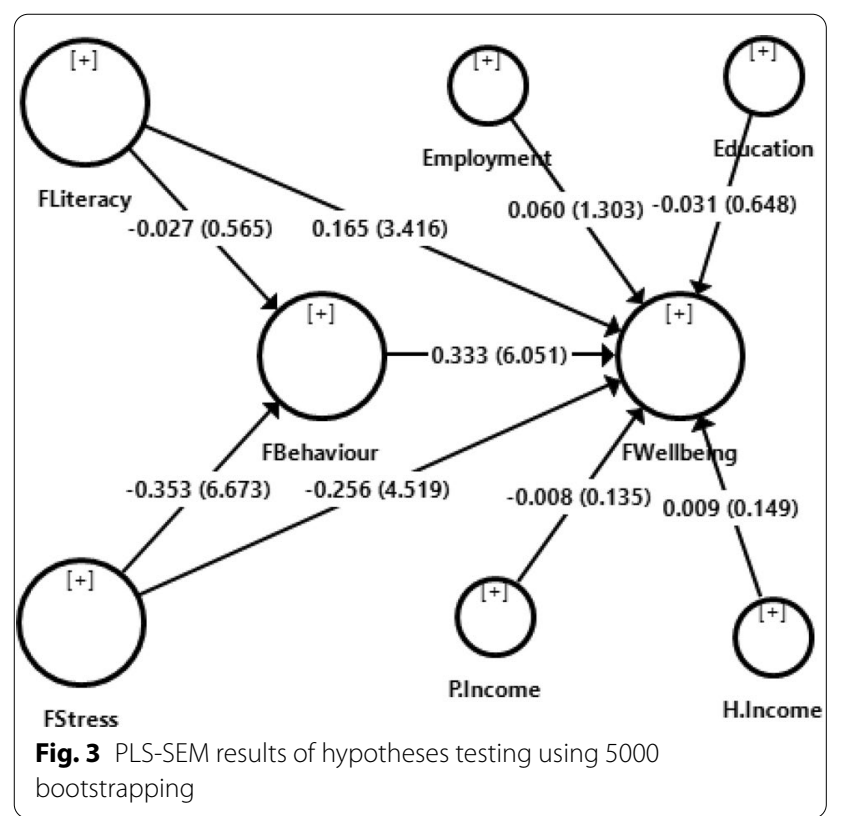


Table 7 Structural model assessment and hypotheses

\begin{tabular}{|c|c|c|c|c|c|c|c|c|}
\hline Hypotheses & & Std. Beta & SE & $t$ value & $95 \% \mathrm{Cl}$ & $R^{2}$ & $f^{2}$ & $Q^{2}$ \\
\hline $\mathrm{H} 1$ & $\mathrm{FB} \rightarrow \mathrm{FWB}$ & ${ }^{* *} 0.333$ & 0.06 & 6.05 & {$[0.23,0.41]$} & 0.283 & 0.122 & 0.143 \\
\hline $\mathrm{H} 2$ & $\mathrm{FL} \rightarrow \mathrm{FWB}$ & ${ }^{* *} 0.165$ & 0.05 & 3.42 & {$[0.09,0.25]$} & & 0.035 & \\
\hline H3 & $\mathrm{FS} \rightarrow \mathrm{FWB}$ & $* *-0.256$ & 0.06 & 4.52 & {$[-0.34,-0.15]$} & & 0.076 & \\
\hline $\mathrm{H} 4$ & $\mathrm{FS} \rightarrow \mathrm{FB}$ & $* *-0.353$ & 0.05 & 6.67 & {$[-0.43,-0.26]$} & 0.121 & 0.135 & 0.067 \\
\hline H5 & $\mathrm{FL} \rightarrow \mathrm{FB}$ & -0.027 & 0.05 & 0.56 & {$[-0.10,0.05]$} & & 0.001 & \\
\hline \multicolumn{9}{|c|}{ Mediating relationships: } \\
\hline $\mathrm{H} 6$ & $\mathrm{FS} \rightarrow \mathrm{FB} \rightarrow \mathrm{FWB}$ & $*^{*}-0.118$ & 0.02 & 4.85 & {$[-0.17,-0.07]$} & & & \\
\hline $\mathrm{H7}$ & $\mathrm{FL} \rightarrow \mathrm{FB} \rightarrow \mathrm{FWB}$ & -0.009 & 0.02 & 0.55 & {$[-0.04,0.02]$} & & & \\
\hline \multicolumn{9}{|c|}{ Controlvariables: } \\
\hline & H.Income & 0.009 & 0.06 & 0.15 & {$[-0.09,0.10]$} & & & \\
\hline & P.Income & -0.008 & 0.06 & 0.14 & {$[-0.11,0.09]$} & & & \\
\hline & Education & -0.031 & 0.05 & 0.65 & {$[-0.11,0.05]$} & & & \\
\hline & Employment & 0.060 & 0.05 & 1.30 & {$[-0.02,0.13]$} & & & \\
\hline
\end{tabular}

Significance at $* * p<0.01 ; \mathrm{FB}=$ Financial behaviour; $\mathrm{FL}=$ Financial literacy; $\mathrm{FS}=$ Financial stress; $\mathrm{FWB}=$ Financial well-being; $\mathrm{H}$.Income $=$ Household monthly income; P.Income $=$ Personal monthly income

Table 8 Out-of-the sample prediction of research model

\begin{tabular}{|c|c|c|c|c|}
\hline \multirow{2}{*}{$\begin{array}{l}\text { Key Endogenous Construct } \\
\text { _FWB }\end{array}$} & \multirow[t]{2}{*}{ Items } & \multirow{2}{*}{$\begin{array}{l}\text { PLS-SEM } \\
\text { RMSE }\end{array}$} & \multirow{2}{*}{$\begin{array}{l}\text { LM } \\
\text { RMSE }\end{array}$} & \multirow[t]{2}{*}{ PLS-SEM-LM } \\
\hline & & & & \\
\hline \multirow{7}{*}{$\begin{array}{l}\text { PLSpredict } Q^{2} \text { of } \\
\text { FWB }=0.26\end{array}$} & FWB1 & 0.704 & 0.699 & 0.005 \\
\hline & FWB2 & 0.766 & 0.759 & 0.007 \\
\hline & FWB3 & 0.728 & 0.728 & 0 \\
\hline & FWB4 & 0.687 & 0.689 & -0.002 \\
\hline & FWB5 & 0.743 & 0.735 & 0.008 \\
\hline & FWB7 & 0.697 & 0.702 & -0.005 \\
\hline & FWB8 & 0.714 & 0.722 & -0.008 \\
\hline
\end{tabular}

$\mathrm{FWB}=$ Financial well-being; Partial least squares structural equation model (Analysis sample); $\mathrm{LM}=$ Linear regression model (Holdout sample); RMSE $=$ Rootmean-squared error

The structural model was initially assessed concerning collinearity between predictor and outcome variables. VIF scores of all the path relationships were ranged from 1.06 to 1.19 which are below 5 demonstrating an acceptable level of collinearity [33], [80]. Following the standard bootstrap procedures, result exhibits that $\mathrm{FB}$ has the largest and positive significant effect of 0.333 on FWB $(\beta=0.333, p<0.01)$ followed by a significant negative impact of FS $(\beta=-0.256, p<0.01)$ and a positive significant effect of FL $(\beta=0.165, p<0.001)$ on FWB. FL and FS were also examined to investigate effect on FB. Results exhibited that FS had a significant negative effect on $\mathrm{FB}(\beta=-0.353, p<0.01)$, whereas the effect of $\mathrm{FL}$ on $\mathrm{FB}$ was insignificant $(\beta=-0.027, p>0.05)$.
Therefore, H1, H2, H3, and H4 were supported. Moreover, using the bootstrapping techniques, mediating hypotheses were examined [33], [80]. Findings supported that although FB was a significant mediator between FS and FWB $(\beta=-0.118, p<0.01), \mathrm{FB}$ was insignificant when investigated as a mediator between FL and FWB ( $\beta=-0.009, p>0.05)$. Hence, H6 was supported but not H7. However, none of the control variables was statistically significant, explaining that the effect of FL, FB and FS on FWB is stable.

\section{Model's prediction accuracy}

Next, the model's in-sample predictive ability was examined by $R^{2}, f^{2}$ and $Q^{2}$. Results in Table 7 show that the theoretical model including four control variables explains $28.3 \%$ variance of financial well-being (FWB) [i.e. $\left.R^{2}=0.283\right]$ which is considered as a close to moderate level of predictive accuracy [12]. Based on the findings, FB is reported as the key variable, followed by FS and FL in predicting FWB. This finding can be acknowledged as satisfactory as only three predictors such as FL, FB, and FS were accounted for in this study.

The $f^{2}$ effect size examines the practical significance of the predictors. Results in Table 7 exhibit that an $f^{2}$ effect size of 0.122 has resulted in $\mathrm{FB} \rightarrow \mathrm{FWB}$, which is close to a moderate level of practical significance [14], whereas a small $f^{2}$ effect size resulted in $\mathrm{FL} \rightarrow \mathrm{FWB}\left(f^{2}=0.035\right)$ and FS $\rightarrow$ FWB $\left(f^{2}=0.076\right)$. This finding also supports that the FB is the important predictors of FWB followed by FS and FL. 
The predictive relevance of theoretical model is also assessed based on the results of cross-validated redundancy $Q^{2}$ value. Using an omission distance, $\mathrm{D}=7, Q^{2}$ value of the FWB is reported as 0.143 which is higher than 0, supporting the model's predictive accuracy [33], [80]. Besides, $q^{2}$ effect size indicates that the relationship $\mathrm{FB} \rightarrow \mathrm{FWB}\left(q^{2}=0.06\right)$ and $\mathrm{FS} \rightarrow \mathrm{FWB}\left(q^{2}=0.04\right)$ have small effect size related to predictive accuracy while it is negligible $\left(q^{2}=0.01\right)$ for the path of FL $\rightarrow$ FWB [33].

Finally, the research model was evaluated for out-ofsample prediction accuracy by setting up a standard algorithm of PLSpredict analysis in Shmueli et al. [83]. The PLSpredict $Q^{2}$ of key endogenous construct (i.e. FWB) was 0.26 , which is higher than 0 . The results in Table 8 explain that the theoretical model has an acceptable level of out-of-sample predictive ability [36, 37]. Next, we examined the indicator level prediction accuracy based on the naïve benchmark such as the root-mean-squared error (RMSE). We compared the RMSE of analysis sample (PLS-SEM) and holdout sample (LM) of each indicator of FWB. The results in Table 8 exhibit that only three indicators of analysis sample such as FWB4, FWB7, FWB8 had lower and FWB3 had equal level of error compared to holdout sample, indicating that the research model entails a moderate level of out-of-sample predictive accuracy $[36,37,83]$.

\section{Discussions}

The study findings offer insights about financial wellbeing of Malaysian low-income households. This study investigated the key antecedent of financial well-being (FWB) of Malaysian low-income (B40) households based on three independent variables, namely financial literacy (FL), financial behaviour (FB), financial stress (FS). The results exhibited that all three hypotheses $(\mathrm{H} 1, \mathrm{H} 2$, and H3) were significantly related to financial well-being. FB and FL have found a positive influence, whereas FS has a negative impact towards financial well-being of the poor urban community. These findings are supported by Ismail and Zaki [45], Mokhtar and Husniyah [58].

$\mathrm{FB}$ is found to be the most influencing factor followed by FS and FL in predicting FWB of low-income group in Malaysia. It is necessary to ensure a better orientation about financial behaviour towards improving financial well-being of the B40 income households. People with a high degree of financial behaviour are better off financially. Sound financial behaviour encompasses maintaining a balance between monthly income and expenditure, paying the bill on time, and considering savings buffer, etc. The results are supported by the previous studies, which state that financial behaviour is positively associated with well-being directly and indirectly [9, 45, 47]. Hence, the policymakers of any nation should understand the nature of financial behaviour of low-income group and design the economic policy.

The B40 group is the most unstable for its financial well-being. This study found a high level of financial stress among respondents which is an essential predictor of financial well-being. The results show that financial stress negatively influences financial well-being of the poor urban community [i.e. Ismail and Zaki [45]]. This means, a higher level of financial stress significantly influences the lower level of financial well-being or vice-versa. The financially disadvantaged Malaysians are less happy with their financial condition as indicated by the low level of financial well-being. As most of them are encountered with high financial stress, financial well-being is not assured. One of the prominent causes would possibly be that low-medium households are going through financial stress due to inadequate earnings allocated for vehicle or house maintenances, loan cash to purchase goods and necessities items and budgetary inadequacies. Grable and Joo [29] reported that credit card debt raises the financial burden of college students. It was found that those with higher rates of self-reported financial stress were less happy with their financial status [56].

Next, financial literacy has found a significant positive influence on financial well-being of the poor urban community in Malaysia. A positive relationship between financial literacy and financial well- being was also reported in prior studies [11,30]. Financial literacy leads positively to well-being and fosters economic development [91]. Joo and Grable [47] asserted that enhanced financial literacy eventually impacts the financial wellbeing of societies. It signposts that financial knowledge about savings, investment, expenditure is essential to ensure financial well-being.

Moreover, financial stress is found to have a significant and negative influence on financial behaviour of the poor urban community in Malaysia. On the other hand, financial literacy is found to have an insignificant influence on financial behaviour. These findings are inline with the prior literature.

Finally, financial behaviour is found to significantly mediate the relationship between financial stress and financial well-being of the poor urban community in Malaysia. It indicates that the presence of financial behaviour weakens the negative influence of financial stress on financial well-being, whereas financial behaviour is found to be an insignificant mediator between financial literacy and financial well-being. 
The results show that although majority respondents (more than 60\%) have an academic degree of Diploma or Bachelor, the level of financial knowledge is poor among B40 group. Hence, it is deduced, traditional educations are not enough to gain financial knowledge when the individuals are other than business discipline.

Furthermore, this investigation has discovered that the individuals' demographic profile, especially their level of education, nature of employment, and level of monthly family earnings substantially differentiate the level of financial well-being, financial behaviour and financial literature. An educated person tends to be exposed to more opportunities than uneducated or low educated individuals. A self-employed person may enjoy independence and contribute a higher income compared to private job holders, whereas government employees enjoy a higher level of job security. Therefore, providing proper education and entrepreneurial opportunities to the Malaysian low-income citizen would help to maintain a higher level of financial well-being.

\section{Conclusion}

Financial well-being is one of the most critical issues in financial management in society. This result indicates that those who practice positive financial habits tend to be extra relaxed with their financial well-being. The financial well-being of an individual can be improved through favourable financial behaviour, sound financial literacy and managing financial stress. This study offers some knowledge and practical implications. Among the three predictors of financial well-being, financial behaviour is an essential aspect followed by stress and literacy in assuring the financial well-being of low-income group people. It is quite necessary to have a fundamental understanding of income, expenditure, and saving pattern, which may drive towards financial security of a family. Although people with low-income level generally struggle to meet up their basic needs, balancing between income and expenditure of a family would be a key aspect an individual should pay serious attention to assure financial well-being. Governmental intervention is a must to make sure that low-income group citizens can earn a reasonable amount of money to mitigate their livings. Besides, a supportive economic policy is necessary to help to manage their financial well-being by providing employment, education, lesson, training, etc.

Financial advisors and consultants may design training programs and/or financial stress management consultation sessions. They must have the financial education to enhance the capacity of individuals to control their financial capital as a legislative initiative. Individuals are required to learn how to face unforeseen changes and adverse financial circumstances, for example, losing job, emergencies issues and health problems. An integrated effort is required by both government and or private regulators- financial institutions, NGOs, members of civil society to improve the financial health of the citizens. The efforts to encourage financial literacy should include providing basic financial education programs covering money management, financial planning, valuation of wealth, risk-return diversification and investment opportunities which will strengthen the financial discipline leading towards well-being. This study also reported that despite having a well-educated group of respondents participated in this research, the effect of financial literacy was lower compared to other antecedents that assure financial well-being. The people with non-business backgrounds may not have a proper introduction with financial knowledge during academic education. Hence, the government should introduce some basic financial literacy courses at academic level so that all the citizen is introduced with a basic financial plan in their daily livings. The government is also required to offer training on financial well-being because the findings indicate that the B40 income groups encounter financial stress along with a moderate level of financial literacy. All these supports may improve financial behaviour, reduce stress, and increase the literacy of lower-income group people of Malaysia.

Despite these implications, this study acknowledges a few limitations that ought to be addressed in future research. Firstly, as the study narrowed down the scope to behavioural factors external to individuals and lowincome group, only three independent variables were regarded as the determinants of financial well-being. Although the findings provide a deep insight about financial well-being of low-income people, future research could employ other behavioural factors such as financial aid seeking, financial self-efficiency, and demographic variables to explore the effects on financial well-being. The inclusion of such factors would enhance the knowledge on financial well-being of low-income individuals. Secondly, the survey was conducted in the area of Klang Valley (i.e. Kuala Lumpur only) due to the largest regarding population size in Malaysia. Future research could cover the geographical sample from different income groups to overcome this challenge such as results generalisation. Thirdly, it would be useful to have the next effort, which integrates both subjective and objective measures of financial well-being. Overall, this study provides a valuable understanding about financial well-being of low-income people by asserting that favourable financial behaviour, managing individual financial stress, and increasing financial literacy would be the key to assuring financial well-being. 


\section{Appendix A}

See Table 9.

Table 9 Measurement scale

\begin{tabular}{|c|c|}
\hline Constructs & Statements \\
\hline \multirow{10}{*}{$\begin{array}{l}\text { Financial Literacy } \\
(1=\text { True, } 0=\text { False })\end{array}$} & FL1. Balance sheet shows your financial status \\
\hline & FL2. We overspend when using savings to buy daily necessities \\
\hline & FL3. Buying insurance is the best investment \\
\hline & FL4. Life insurance protects policy holder from financial burden \\
\hline & FL5. Owning a credit card will increase one's purchasing power \\
\hline & FL6. One can spend more than $20 \%$ of their monthly income for instalments \\
\hline & FL7. All types of investments are profitable \\
\hline & FL8. We can borrow to invest \\
\hline & FL9. In Malaysia we only have a conventional banking system \\
\hline & FL10. Family needs to save three months income for emergencies \\
\hline \multirow{10}{*}{$\begin{array}{l}\text { Financial Behaviour } \\
(1=\text { Strongly disagree to } 5=\text { Strongly agree })\end{array}$} & FB1. I set aside some money for retirement \\
\hline & FB2. I have a plan to reach my financial goals \\
\hline & FB3. I set money aside for savings \\
\hline & RB4. I have a weekly or monthly budget that I follow \\
\hline & FB5. I must cut my living expenses. * \\
\hline & FB6. I run into financial troubles because I do not have enough money. ${ }^{*}$ \\
\hline & FB7. I can afford to buy what I want \\
\hline & FB8. I spend more money than I have. ${ }^{*}$ \\
\hline & FB9. I cannot afford to do things I would enjoy doing. ${ }^{*}$ \\
\hline & FB10. I prefer financial security rather than the amount of savings in my account \\
\hline \multirow{6}{*}{$\begin{array}{l}\text { Financial Stress } \\
(1=\text { Strongly disagree to } 5=\text { Strongly agree })\end{array}$} & FS1. I feel stress about my personal finances in general \\
\hline & FS2. I worry about being able to fulfil monthly financial commitment \\
\hline & FS3. I worry about having enough money to pay for daily expenses \\
\hline & FS4. I feel stress thinking about the total amount of money that I owe \\
\hline & FS5. I feel stress thinking about my credit card debt \\
\hline & FS6. I feel helpless in dealing with the financial problems in my life \\
\hline \multirow{8}{*}{$\begin{array}{l}\text { Financial Well-Being } \\
(1=\text { Very unhappy to } 5=\text { Very happy })\end{array}$} & FWB1. How can you rate your satisfaction with your personal finances? \\
\hline & FWB2. How do you feel about your current financial situation? \\
\hline & FWB3. How secure do you feel about your retirement plan? \\
\hline & FWB4. How confident are you that you will have a financially comfortable retirement? \\
\hline & FWB5. How confident are you of finding the money to pay for a financial emergency cost? \\
\hline & FWB6. How frequently do you find yourself eagerly waiting for the next payday? ${ }^{*}$ \\
\hline & $\begin{array}{l}\text { FWB7. How often you cannot afford financially to enjoy doing things you love with your } \\
\text { friends and family? * }\end{array}$ \\
\hline & FWB8. How often do you worry about being able to meet your monthly living expenses? * \\
\hline
\end{tabular}

* Reverse coded items 


\section{Appendix B}

See Table 10.

Table 10 Normality test

\begin{tabular}{|c|c|c|c|}
\hline Variables & \multicolumn{2}{|c|}{ Skewness } & Kurtosis \\
\hline \multicolumn{4}{|l|}{ Univariate normality } \\
\hline Financial well-being & \multicolumn{2}{|c|}{0.326} & -0.322 \\
\hline Financial behaviour & \multicolumn{2}{|c|}{0.229} & -0.017 \\
\hline Financial stress & \multicolumn{2}{|c|}{0.067} & -0.677 \\
\hline Financial literacy & \multicolumn{2}{|c|}{0.374} & -0.677 \\
\hline Statistics & b & $z$ & $p$ value \\
\hline \multicolumn{4}{|l|}{ Multivariate normality } \\
\hline Skewness & \multicolumn{2}{|r|}{76.861} & 0.000 \\
\hline Kurtosis & \multicolumn{2}{|l|}{24.663} & 0.331 \\
\hline
\end{tabular}

\section{Appendix C}

See Table 11.

Table 11 Multicollinearity test

\begin{tabular}{|c|c|c|c|c|c|c|c|c|c|c|c|}
\hline \multicolumn{12}{|c|}{ Coefficients $^{a}$} \\
\hline \multicolumn{2}{|c|}{ Model } & \multicolumn{2}{|c|}{$\begin{array}{l}\text { Unstandardised } \\
\text { Coefficients }\end{array}$} & \multirow{2}{*}{$\begin{array}{l}\text { Standardised } \\
\text { Coefficients } \\
\text { Beta }\end{array}$} & \multirow[t]{2}{*}{$\mathbf{t}$} & \multirow[t]{2}{*}{ Sig } & \multicolumn{3}{|l|}{ Correlations } & \multicolumn{2}{|c|}{$\begin{array}{l}\text { Collinearity } \\
\text { Statistics }\end{array}$} \\
\hline & & B & Std. Error & & & & Zero-order & Partial & Part & Tolerance & VIF \\
\hline \multirow[t]{4}{*}{1} & (Constant) & 2.673 & 0.268 & & 9.977 & 0.000 & & & & & \\
\hline & FL_SCORE & 0.046 & 0.015 & 0.141 & 3.148 & 0.002 & 0.223 & 0.154 & 0.137 & 0.947 & 1.056 \\
\hline & $A V_{-} F B$ & 0.329 & 0.062 & 0.248 & 5.341 & 0.000 & 0.357 & 0.256 & 0.232 & 0.874 & 1.145 \\
\hline & $A V \_F S$ & -0.170 & 0.030 & -0.275 & -5.761 & 0.000 & -0.395 & -0.274 & -0.251 & 0.833 & 1.201 \\
\hline
\end{tabular}

${ }^{a}$ Dependent Variable: AV_FWB

\section{Appendix D}

See Fig. 4

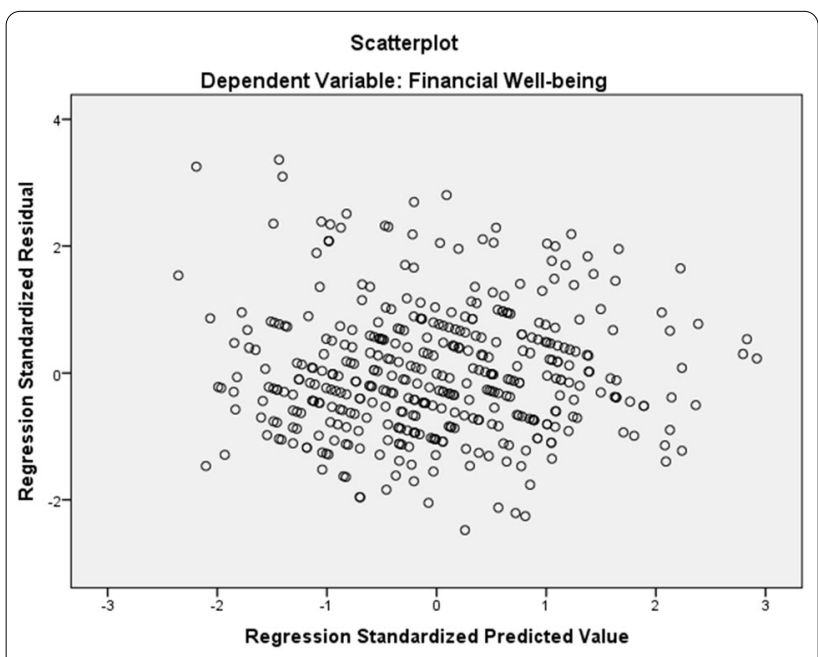

Fig. 4 Homoscedasticity test 


\section{Appendix E}

\section{See Table 12}

Table 12 EFA results for the financial behaviour (FB) construct

\begin{tabular}{|c|c|c|c|c|c|c|c|}
\hline \multirow{2}{*}{$\begin{array}{l}\text { Dimensions of Financial } \\
\text { behaviour (FB) }\end{array}$} & \multirow[t]{2}{*}{ Items } & \multicolumn{2}{|c|}{ Item level } & \multicolumn{2}{|c|}{ Dimension level } & \multirow[t]{2}{*}{ Factor loadings } & \multirow{2}{*}{$\begin{array}{l}\text { Cronbach's } \\
\text { Alpha }\end{array}$} \\
\hline & & Mean & SD & Mean & SD & & \\
\hline \multirow[t]{6}{*}{ Savings behaviour } & FB1 & 3.85 & 0.81 & 3.81 & 0.50 & 0.67 & 0.76 \\
\hline & FB2 & 4.01 & 0.74 & & & 0.66 & \\
\hline & FB3 & 4.01 & 0.71 & & & 0.63 & \\
\hline & FB4 & 3.82 & 0.76 & & & 0.60 & \\
\hline & FB7 & 3.69 & 0.70 & & & 0.54 & \\
\hline & FB10* & 3.47 & 0.82 & & & 0.38 & \\
\hline \multirow[t]{4}{*}{ Expenditure behaviour } & FB9 & 2.95 & 0.93 & 2.86 & 0.67 & 0.75 & 0.69 \\
\hline & FB6 & 2.85 & 1.05 & & & 0.67 & \\
\hline & FB8 & 3.17 & 0.97 & & & 0.55 & \\
\hline & FB5* & 2.48 & 0.84 & & & 0.34 & \\
\hline
\end{tabular}

Kaiser-Meyer-Olkin Measure of Sampling Adequacy =0.77; Significance of Bartlett's Test of Sphericity=0.000; Extraction Method: Principal Axis Factoring; Rotation Method: Varimax with Kaiser Normalisation; *Item FB10 and FB5 were deleted during EFA

\section{Abbreviations}

B40: Bottom 40\%; CMB: Common method bias; CMV: Common method variance; CR: Composite reliability; EFA: Exploratory factor analysis; FB: Financial behaviour; FL: Financial literacy; FS: Financial stress; FWB: Financial well-being; GDP: Gross domestic product; HTMT: Heterotrait-Monotrait ratio of correlations; KMO: Kaiser-Meyer-Olkin; MYR: Malaysian ringgit; MWI: Malaysian Well-being Index; NGOs: Non-government organizations; PAF: Principal axis factoring; PLS-SEM: Partial least squared structural equation modelling; SDGs: Sustainable Development Goals; SEM: Structural equation modelling; SPSS: Statistical Package for the Social Sciences; VIF: Variance inflation factor.

\section{Acknowledgements}

Not applicable.

\section{Authors' contributions}

MR and MS conceived the core idea of the manuscript and conducted empirical studies, analysed the data, and drafted the manuscript. NTC helped with the literature review and discussion. CRI and MMM updated the background, literature review, and discussion. All authors have read and approved the manuscript.

\section{Funding}

We would like to acknowledge the financial support provided by the Fundamental Research Grant Scheme (FRGS) [Grant Number FP058-2017A].

\section{Availability of data and materials}

The datasets used and/or analysed during the current study are available from the corresponding author on reasonable request.

\section{Declarations}

\section{Competing interests}

There is no potential conflict of interests. All authors read and approved the final manuscript.

\section{Author details}

${ }^{1}$ Faculty of Business and Accountancy, University Malaya, 50603 Kuala Lumpur, Malaysia. ${ }^{2}$ Department of Development Studies, Faculty of Economics and Administration, University of Malaya, 50603 Kuala Lumpur, Malaysia. ${ }^{3}$ Department of Marketing, Sunway University Business School, Sunway
University, Subang Jaya, 47500 Bandar Sunway, Malaysia. ${ }^{4}$ School of Business and Economics, United International University, Dhaka, Bangladesh.

Received: 7 July 2020 Accepted: 23 August 2021

Published: 1 November 2021

\section{References}

1. Abdullah N, Sabri MF, Arif AMM (2019) The Relationship between attitude towards money, financial literacy and debt management with young worker's financial well-being. Pertanika J Soc Sci Human 27(1):361-387

2. Agyei SK, Adam AM, Agyemang OS (2019) Financial literacy, cultural dominance, and financial well-being of SME owners in Ghana. Poverty Public Policy 11(3):222-237. https://doi.org/10.1002/pop4.254

3. Ali F, Rasoolimanesh SM, Sarstedt M, Ringle CM, Ryu K (2018) An assessment of the use of partial least squares structural equation modeling (PLS-SEM) in hospitality research. Int J Contemp Hosp Manag 30(1):514538. https://doi.org/10.1108/IJCHM-10-2016-0568

4. Bagozzi RP, Yi Y (1990) Assessing method variance in multitrait-multimethod matrices: THE case of self-reported affect and perceptions at work. J Appl Psychol 75(5):547-560. https://doi.org/10.1037/0021-9010. 75.5.547

5. Bashir S, Zeeshan M, Sabbar S, Hussain RI, Sarki IH (2013) Impact of cultural values and life style on impulse buying behavior: a case study of Pakistan. Int Rev Manag Bus Res 2(1):193-200

6. Bialik K (2018) Americans unhappy with family, social or financial life are more likely to say they feel lonely. https://www.pewresearch.org/ fact-tank/2018/12/03/americans-unhappy-with-family-social-or-finan cial-life-are-more-likely-to-say-they-feel-lonely/

7. Boss P, Bryant CM, Mancini JA (2016) Family stress management: a contextual approach. Sage Publications

8. Bridges S, Disney R (2010) Debt and depression. J Health Econ 29(3):388403. https://doi.org/10.1016/j.jhealeco.2010.02.003

9. Brüggen EC, Hogreve J, Holmlund M, Kabadayi S, Löfgren M (2017) Financial well-being: a conceptualization and research agenda. J Bus Res 79:228-237. https://doi.org/10.1016/j.jbusres.2017.03.013

10. Center for Disease Control and Planning (2018) Health-Related Quality of Life (HRQOL): Well-Being Concepts. https://www.cdc.gov/hrqol/wellb eing.htm 
11. Cheah KK, Foster FD, Heaney R, Higgins T, Oliver B, O'Neill T, Russell R (2015) Discussions on long-term financial choice. Aust J Manag 40(3):414-434. https://doi.org/10.1177/0312896214532476

12. Chin WW (1998) The Partial Least Squares Approach to Structural Equation Modeling. In: Marcoulides GA (ed) Modern methods for business research. Lawrence Erlbaum, pp 295-336

13. Chuah SH-W, Rauschnabel PA, Tseng M-L, Ramayah T (2018) Reducing temptation to switch mobile data service providers over time: The role of dedication vs constraint. Ind Manag Data Syst 118(8):1597-1628. https:// doi.org/10.1108/IMDS-07-2017-0326

14. Cohen J (1988) statistical power analysis for the behavioral sciences, 2nd edn. Psychology Press, London

15. Davis CG, Mantler J (2004) The consequences of financial stress for individuals, families, and society. Centre for Research on Stress, Coping and Well-being. Carleton University, Department of Psychology, Ottawa

16. Delafrooz N, Paim LH (2011) Determinants of financial wellness among Malaysia workers. Afr J Bus Manage 5(24):10092-10100

17. Department of Statistics Malaysia (2020) Malaysia Economic Performance First Quarter 2020. https://www.dosm.gov.my/v1/index.php?r=column/ cthemeByCat\&cat=100\&bul_id=R09wdGZSektvNmw5T1VCeVphN XRqdz09\&menu_id=TE5CRUZCblh4ZTZMODZIbmk2aWRRQT09

18. Department of Statistics Malaysia (2021) Current Population Estimates, Malaysia, 2020. https://www.dosm.gov.my/v1/index.php?r=column/ cthemeByCat\&cat=155\&bul_id=OVByWjg5YkQ3MWFZRTN5bDJiaEVhZz 09\&menu_id=LOpheU43NWJwRWVSZkIWdzQ4TIhUUT09

19. Drentea P, Lavrakas PJ (2000) Over the limit: the association among health, race and debt. Soc Sci Med 50(4):517-529. https://doi.org/10. 1016/S0277-9536(99)00298-1

20. Dvorak T, Hanley H (2010) Financial literacy and the design of retirement plans. J Socio-Econ 39(6):645-652. https://doi.org/10.1016/j.socec.2010. 06.013

21. Falahati L, Sabri MF, Paim LH (2012) Assessment a model of financial satisfaction predictors: examining the mediate effect of financial behavior and financial strain. World Appl Sci J 20(2):190-197

22. Field A (2013) Discovering statistics using IBM SPSS statistics (4th ed). Sage

23. Fitzpatrick SL, Appel LJ, Bray B, Brooks N, Stevens VJ (2018) Predictors of long-term adherence to multiple health behavior recommendations for weight management. Health Educ Behav 45(6):997-1007. https://doi.org/ $10.1177 / 1090198118757823$

24. Franke G, Sarstedt M (2019) Heuristics versus statistics in discriminant validity testing: a comparison of four procedures. Internet Res 29(3):430447. https://doi.org/10.1108/IntR-12-2017-0515

25. Fuller CM, Simmering MJ, Atinc G, Atinc Y, Babin BJ (2016) Common methods variance detection in business research. J Bus Res 69(8):31923198. https://doi.org/10.1016/j.jbusres.2015.12.008

26. Garman ET, Forgue R (2014) Personal finance. Cengage Learning

27. Garman ET, Kim J, Kratzer CY, Brunson BH, Joo S-H (1999) Workplace financial education improves personal financial wellness. Financ Counsel Plan 10(1):79-88

28. Grable JE, Archuleta KL, Nazarinia RR (2011) Financial planning and counseling scales. Springer

29. Grable JE, Joo S-H (2006) Student racial differences in credit card debt and financial behaviors and stress. Coll Stud J 40(2):400-409

30. Grohmann A (2018) Financial literacy and financial behavior: Evidence from the emerging Asian middle class. Pacific-Basin Finance J 48:129-143. https://doi.org/10.1016/j.pacfin.2018.01.007

31. Gutter M, Copur Z (2011) Financial behaviors and financial well-being of college students: evidence from a National Survey. J Fam Econ Issues 32(4):699-714. https://doi.org/10.1007/s10834-011-9255-2

32. Hair JF, Hollingsworth CL, Randolph AB, Chong AYL (2017) An updated and expanded assessment of PLS-SEM in information systems research. Ind Manag Data Syst 117(3):442-458. https://doi.org/10.1108/ IMDS-04-2016-0130

33. Hair JF, Hult GTM, Ringle CM, Sarstedt M (2017) A primer on partial least squares structural equation modeling (PLS-SEM) (2nd ed). Sage Publications

34. Hair JF, Matthews LM, Matthews RL, Sarstedt M (2017) PLS-SEM or CBSEM: updated guidelines on which method to use. Int J Multiv Data Anal 1(2):107-123
35. Hair JF, Ringle CM, Sarstedt M (2011) PLS-SEM: Indeed a Silver Bullet. J Mark Theory Pract 19(2):139-152. https://doi.org/10.2753/MTP10696679190202

36. Hair JF, Risher JJ, Sarstedt M, Ringle CM (2019) When to use and how to report the results of PLS-SEM. Eur Bus Rev 31(1):2-24. https://doi.org/10. 1108/EBR-11-2018-0203

37. Hair JF, Sarstedt M, Ringle CM (2019) Rethinking some of the rethinking of partial least squares. Eur J Mark 53(4):566-584. https://doi.org/10.1108/ EJM-10-2018-0665

38. Henseler J, Ringle CM, Sarstedt M (2015) A new criterion for assessing discriminant validity in variance-based structural equation modeling [journal article]. J Acad Mark Sci 43(1):115-135. https://doi.org/10.1007/ s11747-014-0403-8

39. Hicks S, Tinkler L, Allin P (2013) Measuring subjective well-being and its potential role in policy: perspectives from the UK Office for National Statistics. Soc Indic Res 114(1):73-86. https://doi.org/10.1007/ s11205-013-0384-X

40. Hsiao Y-J, Lin S-J, Dambaravdan C (2016) Financial literacy, savings behavior, and retirement planning in Taiwan. Cross-Strait Bank Finance $4(2): 1-22$

41. Hulland $J(1999)$ Use of partial least squares (PLS) in strategic management research: a review of four recent studies. Strateg Manag J 20(2):195-204

42. Hung A, Parker AM, Yoong J (2009) Defining and measuring financial literacy. RAND Working Paper Series WR-708

43. Hunt SD, Sparkman RD, Wilcox JB (1982) the pretest in survey research: issues and preliminary findings. J Mark Res 19(2):269-273. https://doi.org/ $10.2307 / 3151627$

44. Huston SJ (2010) Measuring financial literacy. J Consum Aff 44(2):296316. https://doi.org/10.1111/j.1745-6606.2010.01170.x

45. Ismail N, Zaki NDA (2019) Does financial literacy and financial stress affect the financial wellness? Int J Modern Trends Soc Sci 2(8):1-11

46. Jacobson BH, Aldana SG, Goetzel RZ, Vardell KD, Adams TB, Pietras RJ (1996) The relationship between perceived stress and self-reported illness-related absenteeism. Am J Health Promot 11(1):54-61. https://doi. org/10.4278/0890-1171-11.1.54

47. Joo S-H, Grable JE (2004) An exploratory framework of the determinants of financial satisfaction. J Fam Econ Issues 25(1):25-50. https://doi.org/10. 1023/B:JEEI.0000016722.37994.9f

48. Judge TA, Ilies R, Dimotakis N (2010) Are health and happiness the product of wisdom? The relationship of general mental ability to educational and occupational attainment, health, and well-being. J Appl Psychol 95(3):454-468. https://doi.org/10.1037/a0019084

49. Kabadayi S, O'Connor GE (2019) Exploring the antecedents of financial well-being: where we are and where we go from here. Int J Bank Mark 37(4):930-933. https://doi.org/10.1108/JJBM-06-2019-338

50. Kaur M, Yadav SS, Gautam V (2013) Financial system development and foreign direct investment: a panel data study for BRIC countries. Glob Bus Rev 14(4):729-742. https://doi.org/10.1177/0972150913501607

51. Kempson E, Finney A, Poppe C (2017) Financial well-being: a conceptual model and preliminary analysis (Final edition). Consumption Research Norway - SIFO

52. Kim J, Garman ET (2003) Financial stress and absenteeism: an empirically derived model. J Financ Counsel Plan 14(1):31-43

53. Kim J, Sorhaindo B, Garman ET (2006) Relationship between financial stress and workplace absenteeism of credit counseling clients. J Fam Econ Issues 27(3):458-478. https://doi.org/10.1007/s10834-006-9024-9

54. Kline RB (2016) Principles and practice of structural equation modeling (4th ed). The Guilford Press

55. Klontz BT, Britt SL (2012) How clients' money scripts predict their financial behaviors. J Financ Plan 25(11):33-43

56. Mahdzan NS, Zainudin R, Sukor MEA, Zainir F, Wan Ahmad WM (2019) Determinants of subjective financial well-being across three different household income groups in Malaysia. Soc Indic Res 146(3):699-726. https://doi.org/10.1007/s11205-019-02138-4

57. Mohd-Any AA, Mutum DS, Ghazali EM, Mohamed-Zulkifli L (2019) To fly or not to fly? An empirical study of trust, post-recovery satisfaction and loyalty of Malaysia Airlines passengers. J Serv Theory Pract 29(5/6):661690. https://doi.org/10.1108/JSTP-10-2018-0223 
58. Mokhtar N, Husniyah A (2017) Determinants of financial well-being among public employees in Putrajaya, Malaysia. Pertanika J Soc Sci Human 25(3):1241-1260

59. Muir K, Hamilton M, Noone J, Marjolin A, Salignac F, Saunders P (2017) Exploring financial wellbeing in the Australian context. University of New South Wales, Sydney, Centre for Social Impact \& Social Policy Research Centre

60. Netemeyer RG, Warmath D, Fernandes D, Lynch JG Jr (2017) How Am I Doing? Perceived financial well-being, its potential antecedents, and its relation to overall well-being. J Consum Res 45(1):68-89. https://doi.org/ 10.1093/jcr/ucx109

61. Nunnally JC (1978) Psychometric theory, 2nd edn. McGraw-Hill, New York

62. O'Neill B, Prawitz A, Sorhaindo B, Kim J, Garman ET (2006) Changes in health, negative financial events, and financial distress/financial well-being for debt management program clients. J Financ Couns Plan 17(2):46-63

63. OECD (2019) OECD Economic Surveys: Malaysia 2019 https://www.oecdilibrary.org/economics/oecd-economic-surveys-malaysia-2019_eaaa4 190-en

64. Osman Z, Madzlan EM, Ing P (2020) In pursuit of financial well-being: the effects of financial literacy, financial behaviour and financial stress on employees in Labuan. Int J Serv Manag Sustain 3(1):55-94. https://doi. org/10.24191/ijsms.v3i1.8041

65. Pavlou PA, Liang $H, X u e Y$ (2007) Understanding and mitigating uncertainty in online exchange relationships: a principal-agent perspective. MIS Q 31(1):105-136. https://doi.org/10.2307/25148783

66. Perry VG, Morris MD (2005) Who is in control? The role of self-perception, knowledge, and income in explaining consumer financial behavior. J Consum Aff 39(2):299-313. https://doi.org/10.1111/j.1745-6606.2005. 00016.x

67. Podsakoff PM, MacKenzie SB, Lee J-Y, Podsakoff NP (2003) Common method biases in behavioral research: a critical review of the literature and recommended remedies. J Appl Psychol 88(5):879-903. https://doi. org/10.1037/0021-9010.88.5.879

68. Potocki T, Cierpiał-Wolan M (2019) Factors shaping the financial capability of low-income consumers from rural regions of Poland. Int J Consum Stud 43(2):187-198. https://doi.org/10.1111/ijcs.12498

69. Prawitz AD, Garman ET, Sorhaindo B, O'Neill B, Kim J, Drentea P (2006) The incharge financial distress/financial well-being scale: Establishing validity and reliability. Financ Counsel Plan Educ 17(1):34-50

70. Ramayah T, Cheah J, Chuah F, Ting H, Memon MA (2018) Partial least squares structural equation modeling (PLS-SEM) using SmartPLS 3.0: an updated and practical guide to statistical analysis (2nd ed). Pearson

71. Remund DL (2010) Financial literacy explicated: the case for a clearer definition in an increasingly complex economy. J Consum Aff 44(2):276-295. https://doi.org/10.1111/j.1745-6606.2010.01169.x

72. Ringle CM, Wende S, Becker J-M (2015) SmartPLS 3. Boenningstedt: SmartPLS GmbH. https://www.smartpls.com

73. Sabri MF, Falahati LF (2013) Predictors of financial well-being among Malaysian employees: examining the mediate effect of financial stress. J Emerg Econ Islam Res 1(3):61-76. https://doi.org/10.24191/jeeir.v1i3.9130

74. Sabri MF, MacDonald M, Hira TK, Masud J (2010) Childhood consumer experience and the financial literacy of college students in Malaysia. Fam Consum Sci Res J 38(4):455-467. https://doi.org/10.1111/j.1552-3934. 2010.00038.x

75. Santini FDO, Ladeira WJ, Vieira VA, Araujo CF, Sampaio CH (2019) Antecedents and consequences of impulse buying: a meta-analytic study. RAUSP Manag J 54(2):178-204

76. Sarker M, Mohd-Any AA, Kamarulzaman Y (2020) Validating a consumerbased service brand equity (CBSBE) model in the airline industry. J Retail Consum Serv 59:102354. https://doi.org/10.1016/j.jretconser.2020.102354

77. Sarstedt M, Bengart P, Shaltoni AM, Lehmann S (2018) The use of sampling methods in advertising research: a gap between theory and practice. Int J Advert 37(4):650-663. https://doi.org/10.1080/02650487. 2017.1348329

78. Sarstedt M, Hair JF, Cheah J-H, Becker J-M, Ringle CM (2019) How to specify, estimate, and validate higher-order constructs in PLS-SEM. Austral Mark J (AMJ) 27(3):197-211. https://doi.org/10.1016/j.ausmj.2019.05.003

79. Sarstedt M, Mooi E (2019) A concise guide to market research: the process, data, and methods using IBM SPSS statistics (3rd ed). Springer, New York. https://doi.org/10.1007/978-3-662-56707-4_9
80. Sarstedt M, Ringle CM, Hair JF (2017) Partial least squares structural equation modeling. In: Homburg C, Klarmann M, Vomberg A (eds) Handbook of market research. Springer, New York, pp 1-40. https://doi.org/10.1007/ 978-3-319-05542-8_15-1

81. Sharma R, Yetton P, Crawford J (2009) Estimating the Effect of Common Method Variance: The Method-Method Pair Technique with an Illustration from TAM Research. MIS Q 33(3):473-490. https://doi.org/10.2307/ 20650305

82. Shen C-H, Lin S-J, Tang D-P, Hsiao Y-J (2016) The relationship between financial disputes and financial literacy. Pac-Basin Finance J 36:46-65. https://doi.org/10.1016/j.pacfin.2015.11.002

83. Shmueli G, Sarstedt M, Hair Joseph F, Cheah J-H, Ting H, Vaithilingam S, Ringle Christian M (2019) Predictive model assessment in PLS-SEM: guidelines for using PLSpredict. Eur J Mark 53(11):2322-2347. https://doi. org/10.1108/EJM-02-2019-0189

84. Steen A, MacKenzie D (2013) Financial stress, financial literacy, counselling and the risk of homelessness. Austral Account Bus Finance J 7(3):31-48

85. Taft MK, Hosein ZZ, Mehrizi SMT, Roshan A (2013) The relation between financial literacy, financial wellbeing and financial concerns. Int J Bus Manag 8(11):63-75

86. Taylor RD, Budescu M, Gebre A, Hodzic I (2014) Family financial pressure and maternal and adolescent socioemotional adjustment: moderating effects of kin social support in low income African American Families. J Child Fam Stud 23(2):242-254. https://doi.org/10.1007/ s10826-012-9688-8

87. Vosloo W, Fouche J, Barnard J (2014) The relationship between financial efficacy, satisfaction with remuneration and personal financial well-being. Int Bus Econ Res J 13(6):1455-1470

88. Wahab NN, Yaacob Z (2018) Strategy for financial well-being among public servants in Malaysia. J Techno Soc 10(2):50-59

89. Walczak D, Pieńkowska-Kamieniecka S (2018) Gender differences in financial behaviours. Inzinerine Ekonomika-Eng Econ 29(1):123-132

90. Wieland A, Durach CF, Kembro J, Treiblmaier H (2017) Statistical and judgmental criteria for scale purification. Supply Chain Manag Int J 22(4):321-328. https://doi.org/10.1108/SCM-07-2016-0230

91. Worthington AC (2006) Predicting financial literacy in Australia. Financ Serv Rev 15(1):59-79

92. Xiao JJ (2008) Applying behavior theories to financial behavior. In: Xiao JJ (ed) Handbook of consumer finance research (pp 69-81). Springer, New York. https://doi.org/10.1007/978-0-387-75734-6_5

93. Xiao JJ, Ahn SY, Serido J, Shim S (2014) Earlier financial literacy and later financial behaviour of college students. Int J Consum Stud 38(6):593-601. https://doi.org/10.1111/ijcs.12122

94. Xue R, Gepp A, O'Neill TJ, Stern S, Vanstone BJ (2019) Financial well-being amongst elderly Australians: the role of consumption patterns and financial literacy. Accounting \& Finance. https://doi.org/10.1111/acfi.12545

\section{Publisher's Note}

Springer Nature remains neutral with regard to jurisdictional claims in published maps and institutional affiliations.

\section{Submit your manuscript to a SpringerOpen ${ }^{\circ}$ journal and benefit from:}

- Convenient online submission

- Rigorous peer review

- Open access: articles freely available online

- High visibility within the field

Retaining the copyright to your article

Submit your next manuscript at springeropen.com 